\title{
Social exclusion and xenophobia: Intolerant attitudes toward ethnic and religious minorities
}

Group Processes \& Intergroup Relations 2014, Vol. 17(3) 371-387

(C) The Author(s) 2013

Reprints and permissions: sagepub.co.uk/journalsPermissions.nav DOI: $10.1177 / 1368430213510569$ gpir.sagepub.com

\author{
Nilüfer Aydin, ${ }^{1}$ Joachim I. Krueger, ${ }^{2}$ Dieter Frey, ${ }^{1}$ \\ Andreas Kastenmüller, ${ }^{3}$ and Peter Fischer ${ }^{3}$
}

\begin{abstract}
The present research investigates the effects of social exclusion on attitudes toward ethnic and religious minorities. Native-born German participants who were socially excluded rather than included reported greater approval for stricter legislation regarding the naturalization of immigrants (Study 1), reported greater prejudice against openly observant Muslims (Studies 2 and 3), and stronger agreement with the view that immigrants are financial burdens to the state (Study 4). Social exclusion threatens the sense of personal control, which in turn leads to stronger rejection of stigmatized outgroups (Study 3). When perceived control was experimentally enhanced, the social exclusion effect disappeared (Study 4). The theoretical and practical implications of these findings are discussed.
\end{abstract}

\section{Keywords}

loss of personal control, outgroup intolerance, prejudice, social exclusion, xenophobia

Paper received 2 July 2012; revised version accepted 19 September 2013.

Attitudes among native-born Germans toward ethnic and religious minority groups have hardened since the mid-1990s (ALLBUS, 2010). One possible cause of this trend is that economic uncertainties and fears of social decline, especially among middle-class individuals, lead to scapegoating and displaced aggression (Heitmeyer, 2006, 2007). Individuals who fear future societal exclusion are more prone to ethnicizing; they become more likely to perceive their social world through the lens of ethnic or racial categories. Current economic conditions in developed European countries provide a context for socially detrimental outcomes (Spiegel Online International, 2012). Economic uncertainties fuel fears of financial decline and loss of social status. As ethnic minorities are highly visible in everyday

\footnotetext{
${ }^{1}$ Ludwig-Maximilians-University München (LMU Munich), Germany

${ }^{2}$ Brown University, USA

${ }^{3}$ University of Regensburg, Germany

Corresponding author:

Nilüfer Aydin, LMU München, Leopoldstr. 13, 80802

Munich, Germany.

Email: Aydin@psy.lmu.de
} 
life, they are a readily available target for discrimination (Zick, Küpper, \& Hövermann, 2011). Given the presence of suggestive field data, the task of experimental work is to address the causal process directly. Hence we ask: Does the threat of social exclusion have a negative effect on attitudes about ethno-religious minorities?

A psychological perspective can address the processes operating at the level of the individual. In this research, we ask whether an experimentally induced state of social exclusion makes individuals less tolerant of minority groups. Further, can such tendencies be understood as an attempt to cope with the experience of exclusion? Our hypothesis is that, compared with individuals who are not excluded, socially excluded individuals are less tolerant of immigrants and Muslim immigrants in particular. We predict this effect because social exclusion threatens the human need of being a valued member of a group. We further predict that the need to exercise control over one's social immediate world links the experience of social exclusion to outgroup prejudice (Williams, 2007, 2009). Specifically, we assume that socially excluded individuals derogate stigmatized outgroups in order to restore their own sense of control. In short, we suggest that expressions of xenophobia and ethnocentrism may function as a compensation for experienced control loss by those who are socially excluded (see also Agroskin \& Jonas, 2010; Duckitt \& Fisher, 2003; Fritsche, Jonas, \& Fankhänel, 2008).

\section{Perceived Threat and Derogation of Minorities}

Adorno and colleagues identified the sense of being personally threatened as one of the roots of The Authoritarian Personality (Adorno, FrenkelBrunswik, Levinson, \& Sanford, 1950). In this tradition, research on the "uncertainty-threat model" has linked political intolerance to elements of personal threat, such as fear of death and system instability (Jost, Glaser, Kruglanski, \& Sulloway, 2003). For example, the motive to decrease perceived threat and uncertainty is associated with political conservatism (Jost et al.,
2003). More specifically, being reminded of the dangers of terrorism releases prejudice and outgroup derogation (Canetti-Nisim, Halperin, Sharvit, \& Hobfoll, 2009), as does the contemplation of one's own death more generally (Cohen, Ogilvie, Solomon, Greenberg, \& Pyszczynski, 2005). In this research, we view social exclusion as a form of "social death" (Williams, 2007) and ask whether the threat of social exclusion strengthens outgroup prejudice. If so, we ask whether the expression of prejudice can be understood as an effort to restore a sense of personal control.

Our approach was to measure anti-immigrant and anti-Muslim attitudes after creating a situation of social exclusion in the laboratory. By measuring the postexclusion deprivation of fundamental needs, particularly control beliefs (Williams, 2009), we sought to hone in on the intervening psychological mechanisms.

\section{Social Exclusion: A Metaphor for Social Death}

Social exclusion refers to formal or informal practices such as ostracism or shunning, designed to punish individuals for violating group norms (Williams, 2007). Social exclusion is a potent stressor for any social mammal, including humans; it makes the individual vulnerable to predation and accidents, and it compromises the body's immune system. Thereby, social exclusion becomes a risk factor for mortality (Sapolsky, 2001). In contemporary Western society, people may not depend as much as their ancestors on social groups for physical survival, but they need social ties as a protection against emotional distress (Williams \& Nida, 2011; Zadro, Williams, \& Richardson, 2004). Individuals can feel sad, angry, fearful, and even suicidal when facing the existential threat of social death (Joiner, 2011). Hence, social exclusion is a source of anxiety, uncertainty, and negative affect (Baumeister \& Leary, 1995).

Typically, socially excluded individuals seek to repair the damage and return to the group. Some behave prosocially or seek out opportunities for affiliation (Maner, DeWall, \& Baumeister, 2007; 
Pickett, Gardner, \& Knowles, 2004). Others turn to antisocial behavior (Williams, 2009) by, for example, displacing aggression (Twenge, Baumeister, Tice, \& Stucke, 2001), withholding help (Twenge, Baumeister, DeWall, Ciarocco, \& Bartels, 2007) or empathy (DeWall \& Baumeister, 2006), or by treating others spitefully (e.g., allocating hot sauce to fellow participants; Kirkpatrick, Waugh, Valencia, \& Webster, 2002). Either type of response can be an attempt to redress the pain of exclusion. In recent years, school shootings and rampage killings have been traced to the experience of being ostracized or bullied (Leary, Kowalski, Smith, \& Phillips, 2003). ${ }^{1}$ If prosocial responses can overcome social exclusion, it is puzzling to see that many individuals opt to respond antisocially and thereby further damage rather than improve their inclusionary status in social groups.

\section{Determinants of Antisocial Behavior After Social Exclusion}

Williams (2009) suggests that coping responses depend on individual and situational factors, although situational determinants appear to play a decisive role in postexclusion aggression (Williams \& Nida, 2011). Initially, individuals face a decrease in their levels of belonging, selfesteem, control, and sense of living a meaningful existence (Zadro et al., 2004); they show physiological responses similar to those associated with physical pain (Eisenberger, Liebermann, \& Williams, 2003). ${ }^{2}$ In a second, reflective, stage, the socially excluded seek to restore and protect their threatened needs. They begin to think and act in alternative ways to meet their frustrated needs (Williams, 2009). If the relational needs of belonging or self-esteem are thwarted, ostracized individuals seek to increase levels of belonging and shore up self-esteem by behaving prosocially (e.g., DeWall, Maner, \& Rouby, 2009; Pickett et al., 2004). If, however, fundamental needs for recognition and control (i.e., a meaningful existence; see Williams, 2009) are thwarted, antisocial responses (like aggressive behavior) are more likely because they seem to offer better prospects of returning to former levels of recognition and control (Buckley, Winkel, \& Leary, 2004; Leary et al., 2003). Williams (2009) argues that postexclusion aggression is an effort to reestablish power and control and thus regain a sense of personal efficacy. Warburton, Williams, and Cairns (2006) exposed ostracized versus included participants to blasts of noise. Half the participants were allowed to control the onset of the noise, whereas the other half had no such control. Subsequently, the ostracized participants without control treated others to more hot sauce than did nonostracized participants or out-of-control participants. When control was restored, ostracized participants were no more aggressive than participants in the inclusion conditions.

The impact of loss of control on aggression toward the social environment is not surprising. People have a basic need to control significant events in their lives (Lefcourt, 1982). However, threats like social exclusion trigger feelings of unpredictability. To restore a sense of predictability, people may seek opportunities to exercise control. If control cannot be direct, they may turn to ingroup bias or system-justifying attitudes (e.g., defending the legitimacy of political institutions and religious system that offer control; see Kay, Gaucher, Napier, Callan, \& Laurin, 2008; Kay, Whitson, Gaucher, \& Galinsky, 2009). Greenaway, Louis, Hornsey, and Jones (2013), for example, argue that perceived terrorist threat and low levels of perceived control strengthen antiimmigrant attitudes. Agroskin and Jonas (2010) showed that perceived lack of control is a strong predictor of ethnocentrism and prejudice toward immigrant groups. Fritsche et al. (2013) showed that when the sense of personal control is threatened, people become more likely to act in ways typical of group members rather than in individuated ways. $^{3}$

Social identity theory (SIT) proposes that the desire to achieve or maintain positive feelings about one's social identity facilitates ingroup favoritism, which includes stereotyping and prejudice under perceived threat (Tajfel \& Turner, 1986). Uncertainty-identity theory (Hogg, 2012; 
Hogg, Meehan, \& Farquharson, 2010), which emerged from SIT, makes more specific predictions. When threatened by uncertainty, people identify more strongly with extremist or ethnocentric groups. Engaging in (political) radicalism may reduce feelings of uncertainty by restoring a sense of predictability and controllability in one's social world.

Based on this body of theory and research, we assume that social exclusion fosters intolerance and prejudice toward members of ethnic and religious outgroups because it threatens personal control beliefs. In Study 1, we examined whether social exclusion negatively affects attitudes toward the naturalization of immigrants in Germany. In Study 2, we explored if inducing social exclusion would intensify anti-Muslim attitudes. In Study 3, we explored control beliefs as the underlying psychological process. Finally, in Study 4, we directly examined the threat-buffering effect of control beliefs on anti-immigrant attitudes, using an established measure to assess prejudices toward immigrants as a dependent variable.

\section{Study 1}

In this first study, we asked participants about their attitudes about the naturalization of immigrants in Germany. During the past decade, the acquisition of citizenship has been a hot-button issue within German political discourse. Policies regulating naturalization have tightened since 2008, and the acquisition of citizenship now requires the passing of a national exam. Against this sociopolitical background, we expected that, compared with controls, socially excluded individuals would support stricter policies toward naturalization.

\section{Participants and Design}

Students at the University of Munich participated in exchange for course credit. The data of two participants who were not German nationals were excluded, leaving an effective sample of 27 women and 15 men, with ages ranging from 18 to $37(M=23.47, S D=3.55)$. Participants were randomly assigned to the social exclusion and the social inclusion conditions.

\section{Method}

Material and procedure. Participants were recruited from psychology classes for a study on German policy. They were asked to provide sociodemographic data, such as their gender, age, and nationality, and then to rate their general political outlook on a Likert scale ranging from 1 (extreme political left) to 10 (extreme political right).

Next, participants were invited to play Cyberball, an Internet ball-tossing game (Williams \& Jarvis, 2006). All participants were tested individually, but led to believe that they were playing with two others via Intranet. In fact, these "other players" were simulated by a computer program. Whenever participants received the ball, they had a choice of where to throw it next. Included participants received the ball about one third of the time, whereas socially excluded participants received the ball twice at the beginning of the game and then never again. The game lasted about 5 minutes with a total of 30 throws.

After the game, participants responded to the questions "How excluded did you feel while playing the ball-tossing game?" and "How uncomfortable did you feel while playing the boll-tossing game?" on a scale from 1 (absolutely not) to 10 (very much). Then, they rated their emotional states on the Positive and Negative Affect Schedule (PANAS; $\alpha=.82$; Watson, Clark, \& Tellegen, 1988). We constructed a composite score by subtracting the score obtained with the negative affect items from the score obtained with the positive affect items so that higher values indicated overall higher levels of positive affect.

During the next stage of the experiment, all participants were asked to read a newspaper clip discussing the requirements for passing the naturalization exam in Germany. ${ }^{4}$ The article reported that due to the strict language assessment test, rates of naturalization were declining and that critics see the difficulty of these tests as an intended barrier to immigrant naturalization. The article also referred to a government proposal 
designed to keep immigrants with a criminal record from becoming citizens. Finally, the article noted that the government agent responsible for the social integration of immigrants vehemently rejected plans to liberalize the requirements for naturalization.

After participants had read the article, they responded to six items assessing their attitudes towards naturalization. They rated their agreement with each of the following statements on a scale from 0 (very strongly disagree) to 5 (very strongly agree): "I think it is alright that the requirements for naturalization are that difficult"; "When you want to get German citizenship, you should be confronted with a difficult language test"; "The requirements for naturalization should be tightened even more"; "We should rigorously clamp down on delinquent immigrants"; and the reverse-scored "Immigrants who have committed a criminal act in the past should be given a chance to get German citizenship" and "Anyone who wants to get naturalized should be naturalized without political barriers." The six-item scale showed high internal consistency $(\alpha=.87)$. After completing the questionnaire, all participants were thanked and thoroughly debriefed.

\section{Results and Discussion}

Manipulation check. Participants in the social exclusion condition felt more socially excluded $(M=6.84, S D=2.24)$ than participants in the social inclusion condition $(M=3.05, S D=2.70)$, $t(40)=4.92, p<.001, \eta p^{2}=.38$. Socially excluded participants also felt more uncomfortable while playing the game $(M=5.00, S D=2.53)$ than socially included participants $(M=2.00, S D=$ 1.71), $t(39.99)=4.48, p<.001, \eta p^{2}=.30$. Furthermore, participants in the social exclusion condition reported less positive affect $(M=1.13$, $S D=0.98)$ than did participants in the inclusion condition $(M=1.74, S D=0.57), t(39.19)=2.52$, $p=.016, \eta \mathrm{p}^{2}=.12$.

Hypothesis test. Participants in the social exclusion condition reported stronger anti-immigrant attitudes towards the naturalization of migrants living in Germany $(M=2.75, S D=1.03)$ than did participants in the social inclusion condition $(M$ $=2.06, S D=1.12), t(40)=2.06, p=.046, \eta p^{2}=$ .10. Political conservatism was positively but weakly associated with anti-immigrant attitudes, $r(42)=.29, p=.06$. However, the effect of social exclusion remained significant, when political persuasion was used as a covariate, $F(1,39)=$ 5.58, $p=.023, \eta \mathrm{p}^{2}=.12 .^{5}$

Having found evidence for the idea that the experience of being socially excluded can cause political intolerance toward immigrants, we sought to replicate this finding with an alternate manipulation of social exclusion and a behavioral measure of political intolerance. Feeling socially excluded may not only lead to increased levels of anti-immigrant attitudes, but it may also result in less tolerant and less prosocial behavior toward ethnic or religious minorities.

\section{Study 2}

The aim of Study 2 was to provide a conceptual replication of Study 1 with improved measures. We investigated whether social exclusion has an impact on intolerant views and behavior toward Muslims living in Germany. We expected that participants in the social exclusion condition would report stronger anti-Muslim attitudes than those in the nonexclusion conditions.

\section{Participants and Design}

Twenty-eight women and 22 men at the University of Munich, with ages ranging from 19 to 50 years $(M=24.70, S D=4.94)$, took part. The design comprised the conditions of social exclusion, social inclusion, and a control. Participants were randomly assigned to the conditions.

\section{Method}

Material and procedure. Participants entered the lab to take part in a study on German policies in exchange for course credit. They provided sociodemographic information variables and rated their political orientation. 
Participants in the social exclusion condition were then asked to read a short paragraph about a situation involving a new job and to take the perspective of the new hire (see Aydin, Fischer, \& Frey, 2010). Participants in the social exclusion condition were told that their colleagues avoided them, as shown by their refusal to go out to have lunch with them, or by withholding assistance with novel or difficult tasks. In contrast, participants in the social inclusion condition were told that they were welcomed by their coworkers who were helpful and eager to make social contact. Participants in the control condition were asked to imagine a new job situation that was neutral in tone and that did not include acts of social exclusion or inclusion by coworkers.

Upon completing a manipulation check ("How excluded did you feel in the described scenario?"; 1 = absolutely not, 10 = very much), ratings of positive and negative affect were provided via PANAS ( $\alpha=.83$ for the composite score).

Next, participants read a newspaper article about the proposed construction of a mosque in Munich. The article provided some information on the project, such as its design and location. It also stated that the mayor had called on residents to show tolerance toward the proposal, citing Munich's reputation as a cosmopolitan and tolerant city. After reading the article, the participants' anti-Muslim views were measured with six items, each rated on a scale from 1 (very strongly disagree) to 6 (very strongly agree). Items assessing anti-Muslim views toward the local practice of Islam were: "As a resident, I would engage vehemently against the mosque-building project"; "Muslims should not practice their religion so publically"; "Muslims should stay in their own group"; and the reversed items "I would agree with the planned mosquebuilding project"; "It is important that minorities can exercise their right to freedom of religion"; and "I think we should be more tolerant toward non-Christian citizens" ( $\alpha=.67)$.

After completing the questionnaire, participants were informed that they had the opportunity to support the mosque project by participating in a signature initiative run by a civil foundation. Each participant received a flyer with the following text:
There is a large conflict going on about the mosque-building project in Munich. Many Munich citizens do not agree with this project and are fighting to stop it. It is uncertain whether this building project will be successful. With your signature, you can support the mosque-building project and stand up for a tolerant and cosmopolitan society. Thank you very much for your support.

Participants were then asked to sign the initiative and thereby lend their support to the mosquebuilding project. After this, participants were thanked and fully debriefed. They learned that the purported initiative to support the mosque project did not actually exist.

\section{Results and Discussion}

Manipulation check. Planned contrast analyses (Rosenthal \& Rosnow, 1985) showed that socially excluded participants reported feelingmore socially excluded $(M=7.78, S D=2.01$; contrast weight: -2) than either included participants $(M=1.46$, $S D=0.64$; contrast weight: 1$)$, and control participants $(M=4.81, \mathrm{~S} D=2.40$; contrast weight: 1), $t(31.29)=8.34, p<.001$. Likewise, socially excluded participants expressed less positive affect $(M=0.35, S D=1.10$; contrast weight: -2$)$ than included participants $(M=1.70, S D=0.73$; contrast weight: $1, p<.001)$, but not control participants $(M=0.73, S D=0.94$; contrast weight: $1, p=.24), t(47)=3.11, p=.003$.

Hypothesis tests. As predicted, ANOVA revealed a significant main effect for anti-Muslim attitudes, $F(2,47)=3.35, p=.043, \eta p^{2}=.12$. Socially excluded participants reported stronger anti-Mus$\lim$ attitudes $(M=2.22, S D=0.82$; contrast weight: 2) than participants in the social inclusion condition $(M=1.73, S D=0.47$; contrast weight: -1$)$ or participants in the control condition $(M=1.74, S D=$ 0.51 ; contrast weight: -1$), t(47)=2.59, p=.013$. $^{6,7}$ Also, as predicted, socially excluded participants were less likely $(25 \%)$ to support the mosque project than participants in the other two conditions (37.5\% in each), $\chi^{2}(1 ; N=50)=6.37, p=.012$. 
Study 2 replicated and extended the findings of Study 1. Social exclusion led to higher levels of anti-Muslim attitudes and to decreased support for free practice of religion. Socially excluded participants were less willing to give their signature to the mosque-building project than were socially included participants and controls. This finding demonstrates that social exclusion does not only have an impact on anti-Muslim views, but that it also impedes prosocial behavior toward Muslim groups.

\section{Study 3}

The aim of Study 3 was to account for the psychological processes transforming the experience of exclusion into xenophobic views. As noted earlier, socially excluded individuals experience a loss of control over their social outcomes (Williams, 2009), and they are also known to exhibit antisocial behavior (Warburton et al., 2006). We therefore hypothesized that the experience of diminished control would stimulate intolerant ideation toward minority groups. This hypothesis is consistent with Williams's (2009) temporal need threat model that proposes that socially excluded people will react in an antisocial manner to fortify threatened personal control caused by the social exclusion experience. We assessed threatened needs after social exclusion in Study 3 (see Jamieson, Harkins, \& Williams, 2010; Zadro et al., 2004), and we used an additional threat condition (disease threat) to investigate whether the threat of social exclusion is unique in its consequences or whether the link from threat to outgroup intolerance is a more general one.

Research suggests that social threats are particularly powerful. Antisocial and self-defeating behavior (Twenge et al., 2001), decreased helping (Twenge et al., 2007), and the reduction of intelligent thought (Baumeister, Twenge, \& Nuss, 2002) were stronger after social exclusion rather than after a nonsocial threat (e.g., to be prone to be a victim of accidents in future life; see Twenge et al., 2001). We therefore tentatively hypothesized that outgroup derogation would be stronger after social exclusion than after other treatments (inclusion, nonsocial threat, control).

\section{Method}

Participants and design. Forty-one women and 35 men (ages ranging from 18 to 47 years; $M=$ $24.33, S D=6.68$ ) were recruited on or near the campus of the University of Munich. They were randomly assigned to the four conditions of social exclusion, social inclusion, nonsocial threat, and neutral control.

Material and procedure. Participants came to the lab to take part in a study of political attitudes. As before, they provided sociodemographic information and indicated their political attitudes. Participants in the social exclusion condition were then asked to recall a life event during which they had experienced severe social exclusion, and to describe it in a short essay. In contrast, individuals in the social inclusion condition were asked to think and write about a life event in which they had felt fully accepted. Participants in the nonsocial threat condition wrote about a time in their life when they felt ill or otherwise compromised in their health status. Participants in the control condition wrote about their activities during the previous day. ${ }^{8}$

After completing the manipulation check ("How excluded did you feel in the situation described by you?"; 1 = absolutely not, $10=$ very much), positive and negative affect were assessed using PANAS ( $\alpha=.84$ for the composite score).

Participants then completed the measures related to the need-threat construct which indirectly assess threat perception after episodes of ostracism by indicating need satisfaction (CarterSowell, Chen, \& Williams, 2008; Williams, 2009; Zadro et al., 2004). The Need-Threat Scale comprises 20 items (adapted from Jamieson et al., 2010) with separate subscales for the need to belong, self-esteem, meaningful existence, and control. Participants rated the feelings they experienced during the essay-writing task on 5-point scales $(1=$ not at all, $5=$ extremely) with lower values indicating higher perceived threat caused 
by social exclusion. Sample items are: belonging ("I felt very accepted by others"; $\alpha=.83$ ), self-esteem ("I felt good about myself"; $\alpha=.86$ ), control ("I felt powerful"; $\alpha=.77$ ), and meaningful existence (" $I$ felt useful'; $\alpha=.79)$.

Next, participants read a newspaper article describing a mosque construction project in Munich. The stimulus material and dependent variable (a six-item anti-Muslim scale) were identical to the ones used in Study $2(\alpha=.78)$. Finally, all participants were thanked for their contributions and thoroughly debriefed.

\section{Results and Discussion}

Manipulation check. Planned contrasts showed that socially excluded participants indeed felt as intended $(M=7.65, S D=2.20)$ as compared with included participants, $(M=1.37, S D=0.49, p<$ $.001)$; controls, $(M=2.17, S D=1.46, p<.001)$, or those exposed to a nonsocial threat condition $(M=5.44, S D=3.16, p=.001), t(36.98)=8.56$, $p<.001$. There was no overall effect of social exclusion on (positive) affect, $F<1$.

Hypothesis tests. There was a (marginally) significant effect for anti-Muslim attitudes, $F(3,72)=$ $2.71, p=.051, \eta \mathrm{p}^{2}=.10$. As predicted, socially excluded participants reported stronger antiMuslim attitudes $(M=2.94, S D=1.03)$ than did socially included participants $(M=2.35, S D=$ $1.03)$, controls $(M=2.35, S D=0.72$, or nonsocially-threatened participants $(M=2.09, S D=$ 1.11), $t(72)=2.74, p=.008$.

Threatened needs. A one-way multivariate analysis of variance (MANOVA) with the threatened needs as the dependent measures revealed a multivariate main effect (Wilks's $\Lambda=.29), F(12$, $182.84)=9.14 p<.001, \eta p^{2}=.34$. Univariate ANOVAs yielded main effects for the need to belong, $F(3,72)=33.32, p<.001, \eta p^{2}=.58$, meaningful existence, $F(3,72)=27.12, p<.001$, $\eta \mathrm{p}^{2}=.51$, self-esteem, $F(3,72)=34.62, p<.001$, $\eta \mathrm{p}^{2}=.59$, and personal control belief, $F(3,72)=$ 11.10, $p<.001, \eta p^{2}=.32$. Post hoc analyses (least significant difference [LSD]) revealed that socially excluded participants showed less satisfaction of belonging needs compared with the other three conditions, $p<.001$. Moreover, the socially excluded revealed less belief in personal control, meaningful existence, and self-esteem compared with controls and the socially included, ps $<.005$, but not compared with participants exposed to nonsocial threats (meaningful existence, $p=.11$; self-esteem, $p=.29$; control, $p=$ .52). Table 1 shows the relevant descriptive statistics. Table 2 shows the correlations among the subscales.

Mediational analyses. A key element of our psychological process model is the idea that a sense of threatened personal control mediates the effect of social exclusion on anti-Muslim attitudes. A preliminary correlational analysis showed the following: There was a negative association between anti-Muslim attitudes and personal control beliefs, $r(76)=-.31, p=.007$. Using Hayes and Preacher's (in press) script (5,000 bootstraps) for a multicategorical predictor (social exclusion, social inclusion, and control group condition), we calculated the direct and indirect effects. ${ }^{10}$ We created two dummy codes (inclusion condition and control group condition, coded 1) and the reference group (exclusion condition, coded 0 ). There was a (marginally) significant direct effect of social exclusion (vs. control group condition) on anti-Muslim attitudes, $t=1.98 p=.052$, which vanished when the mediator was controlled, $t=$ $-0.92, p=.36$. The indirect effect lay within a $95 \%$ confidence interval bounded by -0.77 and -0.04 . Analysis also showed a marginal direct effect of social exclusion (vs. social inclusion) on anti-Muslim attitudes, $t=1.98, p=.052$, which disappeared when the mediator of control beliefs was accounted for, $t=-0.48, p=.63$. The indirect effect lay between -1.01 and -0.05 with $95 \%$ confidence.

Thus, it appears that personal control beliefs mediate the effect of social exclusion on antiMuslim attitudes relative to the control and social inclusion condition. The observed mediation is consistent with the predictions derived from the need-threat model suggesting that thwarted levels 
Table 1. Means $(M)$ and standard deviations $(S D)$ for anti-Muslim attitudes and fundamental needs satisfaction in Study 3.

\begin{tabular}{|c|c|c|c|c|c|c|c|c|}
\hline & \multicolumn{8}{|c|}{ Experimental condition } \\
\hline & \multicolumn{2}{|c|}{ Exclusion } & \multicolumn{2}{|c|}{ Inclusion } & \multicolumn{2}{|c|}{ Control } & \multicolumn{2}{|c|}{ Nonsocial threat } \\
\hline & $M$ & $S D$ & $M$ & $S D$ & $M$ & $S D$ & $M$ & $S D$ \\
\hline Anti-Muslim attitudes & 2.95 & 1.04 & 2.35 & 1.03 & 2.35 & 0.73 & 2.09 & 1.11 \\
\hline Feelings of acceptance & 3.10 & 1.37 & 6.38 & 0.36 & 4.61 & 0.77 & 4.28 & 1.34 \\
\hline Self-esteem & 2.71 & 1.02 & 5.80 & 0.68 & 4.15 & 1.25 & 3.07 & 1.15 \\
\hline Meaningful existence & 3.60 & 0.90 & 6.11 & 0.47 & 4.45 & 0.86 & 4.09 & 1.35 \\
\hline Control belief & 2.81 & 0.96 & 4.60 & 1.04 & 4.07 & 1.33 & 3.05 & 1.16 \\
\hline
\end{tabular}

Note. Higher values indicate greater anti-Muslim attitudes and greater needs fulfilment. $N=76$.

Table 2. Intercorrelations between the dependent variable anti-Muslim attitudes and fundamental needs in Study 3 .

\begin{tabular}{llllll}
\hline & 1 & 2 & 3 & 4 & 5 \\
\hline 1. Anti-Muslim attitudes & - & & & & \\
2. Feelings of acceptance & -.19 & - & & & \\
3. Self-esteem & $-.28^{*}$ & $.80^{* * *}$ & - & & \\
4. Meaningful existence & -.21 & $.80^{* * *}$ & $.81^{* * *}$ & - & \\
5. Control belief & $-.31^{* *}$ & $.57^{* * *}$ & $.70^{* * *}$ & $.68^{* * *}$ & \\
\hline
\end{tabular}

Note. Higher values indicate greater anti-Muslim attitudes and greater needs fulfilment.

$* * * p<.001 ; * * p<.01 ; * p<.05$.

of internal control beliefs may result in increased antisocial attitudes (Warburton et al., 2006). AntiMuslim attitudes were also correlated with political persuasion, $r(75)=.43, p<.001$, but this covariate did not eliminate the effect of social exclusion on anti-Muslim attitudes, when it was added to the model, $F(3,70)=3.96, p=.011$, $\eta \mathrm{p}^{2}=.14$.

Anti-Muslim attitudes did not correlate with threatened meaningful existence, $r(76)=-.21, p$ $=.06$, or feelings of acceptance, $r(76)=-.19, p=$ .09. Thus, these needs did not mediate the link between social exclusion and anti-Muslim attitudes. Moreover, a significant correlation between anti-Muslim attitudes and state self-esteem was observed, $r(76)=-.28, p=.016$. However, selfesteem did not function as a mediating variable (the confidence interval for self-esteem included zero $[-0.263,0.003]$, indicating that it had a nonsignificant indirect effect on anti-Muslim attitudes).

Study 3 replicated and extended the findings of Studies 1 and 2. Socially excluded individuals showed higher levels of intolerance towards Muslims than did included participants, controls, or individuals subjected to a nonsocial threat. Although the latter perceived the situation as equally threatening as did participants in the social exclusion condition, they did not show as much anti-Muslim sentiment as did socially excluded individuals. Study 3 also shed some light on the underlying psychological process. Compared with participants in the social inclusion and control conditions, participants feeling excluded perceived themselves as less self-efficient and in control of their social environment. This result fits with Williams's (2009) need-threat model of ostracism, which assumes that antisocial responses after 
social exclusion primarily depend on the degree to which control needs are thwarted. Contrary to our original expectations, however, we found that participants in the nonsocial threat condition also experienced a loss of personal control. Upon reflection, this result is not surprising. Thinking about a disease may equally threaten one's sense of control like a social threat.

\section{Study 4}

Having found replicable evidence for the idea that social exclusion can reduce political and social tolerance toward Muslim and immigrant groups, we now turn to the question of whether these outcomes are preventable. In Study 3, we saw that loss of control mediates the relationship between social exclusion and social intolerance, but path analyses can only suggest-not establish-causal hypotheses. We therefore designed Study 4 as a test of the modus tollens version of our hypothesis. To wit, if prejudice after social exclusion stems from the experience of lost control, and if antisocial responses to social exclusion are a form of reclaiming control (Warburton et al., 2006; Williams, 2007), then the recovery of a sense of control should allow greater tolerance for outgroups.

\section{Method}

Participants and design. Forty-nine women and 13 men (aged 19 to 39 years; $M=22.73, S D=3.33$ ) at the University of Munich took part in exchange for course credit. They were randomly assigned to the conditions of a 2 (exclusion status: social exclusion vs. inclusion) x 2 (control prime: yes vs. no) independent-groups design.

Material and procedure. Participants were run individually. After providing demographic information and indicating their political persuasion, they wrote a short paragraph in response to the newjob scenario, again with the instruction to take the view of the new employee. The social exclusion manipulation was identical to the one employed in Study 2.
Upon completing the manipulation check (as in the prior experiments), participants rated their feelings on the PANAS $(\alpha=.84)$. Next, they were asked to write a short essay. Individuals in the high control condition read:

We are now interested in hearing about a situation in your life in which you perceived yourself as particularly powerful, and where you had the feeling that you had everything under control. Please briefly describe this incident and how you felt in this situation.

In contrast, participants in the noncontrol salience condition read:

We are now interested in hearing about a situation in your life in which you perceived yourself as particularly powerless, and where you had the feeling that you had nothing under control. Please briefly describe this incident and how you felt in this situation.

After receiving the instructions, the participants wrote their essays.

To test whether participants in the control salience condition felt more empowered in their social environment, they were asked to rate "How much control did you feel in the situation described?" (1 $=$ not at all, $10=$ very much). The critical dependent measure was an estimate of the costs caused by immigrants (Balke, El-Menouar, \& Rastetter, 2009). Participants were asked to indicate their agreement with four items ( $1=$ absolutely not, $6=$ very much): "Foreigners increase crime rates"; "Foreigners take jobs away"; and the two reversed items "Foreigners are good for the economy" and "Foreigners make people more open to new ideas and cultures" ( $\alpha=$.64). Afterwards, the participants were thanked by the experimenter and debriefed.

\section{Results and Discussion}

Manipulation check. Participants in the social exclusion conditions felt more excluded $(M=7.86$, $S D=1.94)$ than those in the social inclusion 


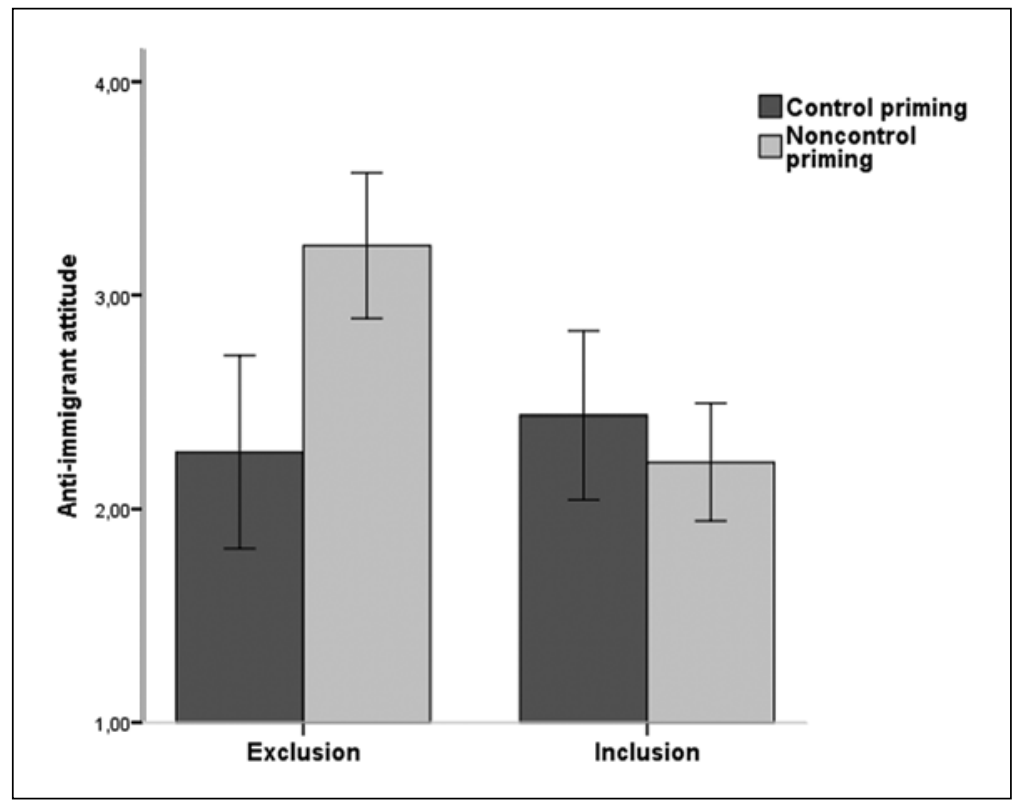

Figure 1. The effect of social exclusion (exclusion vs. inclusion) and control salience (control vs. noncontrol) on anti-immigrant attitudes in Study 4. Error bars represent \pm 2 SE.

conditions $(M=2.34, S D=1.99), t(60)=11.03, p$ $<.001, \eta \mathrm{p}^{2}=.67$. Also, participants in the control priming condition reported feeling more control in the situation described $(M=8.48, S D=1.52)$ than did participants in the noncontrol priming condition $(M=3.48, S D=2.80), t(50)=8.07, p<$ $.001, \eta \mathrm{p}^{2}=.56$. Finally, socially excluded participants reported less positive affect $(M=1.00, S D$ $=1.07)$ than did socially included participants $(M$ $=1.55, S D=.89, t(60)=2.21, p=.031, \eta p^{2}=$ .076 .

Hypothesis tests. A 2 (status of social exclusion) $\mathrm{x}$ 2 (priming) ANOVA revealed main effects for status of exclusion, $F(1,58)=5.07, p=.028, \eta \mathrm{p}^{2}$ $=.08$, and control prime, $F(1,58)=4.00, p=.05$, $\eta \mathrm{p}^{2}=.065$ (see Figure 1). The interaction effect was also significant, $F(1,58)=10.05, p=.002$, $\eta \mathrm{p}^{2}=.15$. Simple effects analyses revealed that socially excluded participants in the noncontrol priming condition reported higher levels of antiimmigrant attitudes (that foreigners would cause more costs and disadvantages for Germany;
$M=3.23, S D=0.63)$ than did socially excluded participants who were primed with control $(M=$ 2.26, $S D=0.90), F(1,58)=12.93, p=.001$. No difference was found between included participants in the control and noncontrol conditions, $F<1 .{ }^{11}$ Again, political orientation was correlated with anti-immigrant attitudes, $r(61)=.35, p$ $=.006$. Yet, the theoretically relevant interaction effect remained significant when this variable was used as a covariate, $F(1,56)=8.88, p=.004$, $\eta \mathrm{p}^{2}=.14$.

The findings of Study 4 corroborated the central hypothesis, namely that intolerance toward immigrants can be buffered among socially excluded individuals when they are reminded of life events during which they had felt control. In contrast, socially excluded participants who received a noncontrol prime showed significantly higher levels of prejudice toward migrants than did participants in the other three conditions. We conclude that helping people to restore a sense of control over their lives can prevent intolerance after social exclusion. 


\section{General Discussion}

The aim of this research was to address the question of whether socially excluded individuals respond with higher levels of political and social intolerance toward ethnic and religious minorities in order to cope with and redress their experience of being excluded.

Guided by previous theory and research including early efforts to understand anti-Semitism, ethnocentrism, and willingness to accept totalitarian regimes, we hypothesized that a sense of loss of control after social exclusion leads to greater outgroup derogation.

In four studies, we found that heightened levels of intolerance toward immigrants and Muslims living in Germany emerged as a response to the psychological threat posed by social exclusion. Socially excluded participants supported restrictive naturalization policies (Study 1) and showed less tolerance toward Muslims practicing Islam in Germany (Studies 2 and 3). Preexisting political attitudes could not fully explain the "intolerance" shift in participants' views toward minority groups. Finally, we found that priming the socially excluded with a sense of personal control buffered prejudice toward immigrants (Study 4). This finding sits well within a pattern of results suggesting that ostracism lowers the perception of control, which in turn accounts for antisocial responses as a method of restoring or fortifying social control (Warburton et al., 2006; Williams, 2009).

Interestingly, neither deprived self-esteem, nor a damaged sense of living a meaningful existence seems necessary for social exclusion to trigger prejudice. A compromised sense of personal control is sufficient. When we separated and studied these constructs individually, we were able to offer a more differentiated picture of the psychological coping strategies engaged by social exclusion. Only control belief, and no other need construct, mediated the relationship between feelings of exclusion and outgroup intolerance (Study 3). This result aligns with Williams's (2009) need-threat model of ostracism.

Our results cohere with related findings linking perceptions of threat to outgroup derogation.
Studies conducted in the context of terror management theory (Greenberg, Pyszczynski, \& Solomon, 1986) and uncertainty-threat theory (Jost et al., 2003) suggest that the threat posed by physical death raises levels of prejudice and political intolerance. Results of our studies lend further credence to these ideas, inasmuch as social exclusion can be seen as a form of social death (Case \&Williams, 2004). Metaphorically speaking, the xenophobia seen among the socially excluded may be a misguided survival strategy.

\section{Limitations}

The data on postexclusion affect are somewhat mixed. Studies 1, 2, and 4, but not Study 3, show a significant impact of social exclusion. Moreover, affect did not correlate with anti-immigrant and anti-Muslim attitudes in any of the studies ruling out the possibility that respondents were more prejudiced because they were in a more negative mood state. These inconsistencies may be understood in light of work reported by Bernstein and Claypool (2012), which suggests that differences in the perceived severity of social exclusion can yield different responses. For example, the prospect of deep and lasting social isolation can be so painful that it triggers emotional numbing, whereas being left out in a game of Cyberball may be experienced as a temporary setback that people respond to with emotional hypersensitivity. Our results suggest that reliving a personal episode of exclusion (through the essay-writing task in Study 3) is an experience of the former type, whereas being sidelined in Cyberball (Study 1) and the scenario task (Studies 2 and 4) are only as moderately painful and thus followed by emotional hypersensitivity. This interpretation can only be tentative. Future research should leverage severity of the social exclusion experience as a possible moderator of the path from social exclusion to outgroup derogation.

Another limitation concerns the discriminant validity of the measurements we used to assess threatened needs (Study 3). We believe that our strategy to separately analyze subscales of threatened needs is more useful in order to explore and 
understand the psychological mechanisms underlying outgroup derogation. Nevertheless, as the subscales of the Need-Threat Scale (see Jamieson et al., 2010) highly correlate with one another, it is difficult to disentangle theoretical distinct constructs like control or self-esteem. The use of additional valid measures of motivational needs would be helpful to ensure the discriminant validity of the theoretical constructs.

Finally, we used traditional explicit measures of outgroup intolerance, which are vulnerable to strategic displays, and social desirability biases are of particular concern (Dovidio, Kawakami, Johnson, Johnson, \& Howard, 1997). To reduce bias, future research may also include implicit measures. For example, the evaluative decision task in which persons judge the affective connotation of a target word (Fazio, Sanbonmatsu, Powell, \& Kardes, 1986) or novel procedures such as the sorting of paired features task, which measures four separate associations in a single response block (SPF; Bar-Anan, Nosek, \& Vianello, 2009) are promising in this regard.

\section{Future Research and Implications}

Our findings suggest that social exclusion can contribute to intolerance toward certain minority groups. In contemporary German society, immigrant groups, and Muslims in particular, are targets of xenophobia. Future research may explore the generalizability of these findings to other national and ethnic contexts. Some scholarly work suggests that this might be so. Once a negative perspective on an outgroup develops, it generalizes fairly easily to others. Individuals who are intolerant toward a certain group tend to be less favorable toward other groups (Adorno et al., 1950). It remains to be seen whether intolerant attitudes toward other minority groups like homosexuals, disabled persons, or persons suffering from HIV disease may also serve as a strategy to cope with the aversive state of being socially excluded.

There is also a need to study whether the psychological process model we sketched and tested, can be applied to members of minority or immigrant groups. On the one hand, we know that in German opinion polls, $46 \%$ of respondents agree that there are too many Muslims in Germany and nearly 55\% claim that Muslims are too demanding (Zick, Küpper, \& Wolf, 2010). Moreover, European surveys show a generalized belief that Muslim immigrants are fanatical, violent, and unwilling to integrate into the host society (e.g., PEW Research Center, 2011). On the other hand, there is evidence that many Muslim immigrants of the second and third generation feel rejected by their host societies and express unfavorable opinions about the Western world (PEW Research Center, 2011). Some scientists argue that feelings of exclusion may result in higher susceptibility to extreme political and religious beliefs and viewpoints in (young) Muslim immigrants (Kruglanski \& Orehek, 2011; Schaafsma \& Williams, 2012).

This assumption is empirically supported by previous work on social exclusion demonstrating that socially excluded people will react in an aggressive manner to fortify needs of control and recognition (Twenge et al., 2001; Warburton et al., 2006; Williams, 2009). Also, work by Schaafsma and Williams (2012) showed that perceived exclusion by ethnic outgroup members leads to more hostility toward the excluder and to increased negativity toward the excluder's outgroup as a whole compared to exclusion by an ingroup member. We suspect that the widespread experience of social exclusion has damaging effects well beyond individual suffering. Feelings of exclusion may impede a successful integration of Muslim immigrants in the European host nations; they may even motivate immigrants to more strongly assert their ethnic and religious identity. At the same time, experiences of social exclusion may be one fundamental factor for the growing number of people supporting right-wing populists all across Europe (Spiegel Online International, 2010). This development compromises democratic structures and may lead to a state of political destabilization in European countries. The research reported in this article and similar work does not suggest that social inclusion is a panacea against radicalization and 
xenophobia, but it may be part of a broader strategy to address the problem.

\section{Funding}

This research received no specific grant from any funding agency in the public, commercial, or not-forprofit sectors.

\section{Notes}

1. Most of the experimental studies on ostracism, rejection, and social exclusion support the exclusion-aggression hypothesis by showing that socially excluded individuals are more inclined to exhibit aggressive and antisocial behavior than prosocial behavior (Leary, Twenge, \& Quinlivan, 2006).

2. Bernstein and Claypool (2012) showed that the severity of social pain corresponds to the severity of the exclusion experience.

3. Research shows that control deprivation may play a role in outgroup derogation. However, there are other potential variables that could be confounded with outgroup intolerance. Such variables include self-esteem (Leary, 2007), authoritarianism (RWA; Altemeyer, 1996), and social dominance orientation (SDO; Sidanius \& Pratto, 1999).

4. The stimulus material was adapted from an original newspaper article published on Focus Online (2009).

5. Age, affect, and gender do not correlate with the main dependent variable in any of the four studies. Therefore, these variables are not treated as possible covariates in the present studies.

6. Bonferroni correction was applied to the planned contrast analyses.

7. There was no significant correlation observed for political persuasion and anti-Muslim attitude, $p>.14$.

8. Participants were not given a time limit for this task.

9. Bonferroni corrections were applied. We also conducted post hoc analyses (LSD) and found that socially excluded participants differed from participants in the nonsocial threat condition regarding anti-Muslim views, $p=.010$ and marginally from participants in the inclusion and control condition, both $p$ s $=.06$.

10. Participants in the social exclusion and the nonsocial threat condition did not differ regarding personal control belief, $p>.52$. Therefore, only the key mediational analyses between social exclusion and the control conditions (inclusion and neutral conditions) are reported.

11. Simple effect analysis showed that there was no significant difference between socially excluded and included participants primed with a sense of control, $F<1, p>.51$.

\section{References}

Adorno, T., Frenkel-Brunswik, E., Levinson, D., \& Sanford, N. (1950). The authoritarian personality. New York, NY: Harpers.

Agroskin, D., \& Jonas, E. (2010). Out of control: How and why does perceived lack of control lead to ethnocentrism? Review of Psychology, 17, 79-90.

Allgemeine Bevölkerungsumfrage der Sozialwissenschaften (ALLBUS). (2010). Jahresbericht 2010 [Anual report 2010]. Retrieved from http://nbn-resolving.de/urn:nbn:de:0168-ssoar-256420

Altemeyer, B. (1996). The authoritarian specter. Cambridge, MA: Harvard University Press.

Aydin, N., Fischer, P., \& Frey, D. (2010). Turning to God in times of ostracism: The impact of social exclusion on religiousness. Personality and Social Psychology Bulletin, 36, 742-753. doi:10.1177/0146167210367491

Balke, D., El-Menouar, Y., \& Rastetter, R. U. (2009). Einschätzungen von Kosten durch Zuwanderer [Assessment of costs caused by immigrants]. In A. Glöckner-Rist (Ed.), Zusammenstellung sozialwissenschaftlicher Items und Skalen. ZIS Version 13.00. Bonn, Germany: GESIS.

Bar-Anan, Y., Nosek, B. A., \& Vianello, M. (2009). The sorting paired features task: A measure of association strengths. Experimental Psychology, 56, 329-343. doi:10.1027/1618-3169.56.5.329

Baumeister, R. F., \& Leary, M. R. (1995). The need to belong: Desire for interpersonal attachments as a fundamental human motivation. Psychological Bulletin, 117, 497-529. doi:10.1037/0033-2909.117.3.497

Baumeister, R. F., Twenge, J. M., \& Nuss, C. K. (2002). Effects of social exclusion on cognitive processes: Anticipated aloneness reduces intelligent thought. Journal of Personality and Social Psychology, 83, 817-827. doi:10.1037/0022-3514.83.4.817

Bernstein, M. J., \& Claypool, H. M. (2012). Social exclusion and pain sensitivity: Why exclusion sometimes hurts and sometimes numbs. Personality and Social Psychology Bulletin, 38, 185-196. doi:10.1177/0146167211422449

Buckley, K. E., Winkel, R. E., \& Leary, M. R. (2004). Reactions to acceptance and rejection: Effects of level and sequence of relational evaluation. 
Journal of Experimental Social Psychology, 40, 14-28. doi:10.1016/S0022-1031(03)00064-7

Canetti-Nisim, D., Halperin, E., Sharvit, K., \& Hobfoll, S. E. (2009). A new stress-based model of political extremism. Journal of Conflict Resolution, 53, 363-389. doi:10.1177/0022002709333296

Carter-Sowell, A. R., Chen, Z., \& Williams, K. D. (2008). Ostracism increases social susceptibility. Social Influence, 3, 143-153. doi:10.1080/15534510802204868

Case, T. I., \& Williams, K. D. (2004). Ostracism: A metaphor for death. In J. Greenberg, S. L. Koole, \& T. Pyszczynski (Eds.), Handbook of experimental existential psychology (pp. 336-351). New York, NY: Guilford Press.

Cohen, F., Ogilvie, D. M., Solomon, S., Greenberg, J., \& Pyszczynski, T. (2005). American roulette: The effect of reminders of death on support for George W. Bush in the 2004 presidential election. Analyses of Social Issues and Public Policy, 5, 177-187. doi:10.1111/j.1530-2415-2005-00063.x

DeWall, C. N., \& Baumeister, R. F. (2006). Alone but feeling no pain: Effects of social exclusion on physical pain tolerance and pain threshold, af fective forecasting, and interpersonal empathy. Journal of Personality and Social Psychology, 91, 1-15. doi:10.1037/0022-3514.91.1.1

DeWall, C. N., Maner, J. K., \& Rouby, D. A. (2009). Social exclusion and early-stage interpersonal perception: Selective attention to signs of acceptance. Journal of Personality and Social Psychology, 96, 729-741. doi:10.1037/a0014634

Dovidio, J. F., Kawakami, K., Johnson, C., Johnson, B., \& Howard, A. (1997). The nature of prejudice: Automatic and controlled processes. Journal of Experimental Social Psychology, 33, 510-540. doi:10.1006/ jesp.1997.1331

Duckitt, J., \& Fisher, K. (2003). The impact of social threat on worldview and ideological attitudes. Political Psychology, 24, 199-222. doi:10.1111/0162895X.00322

Eisenberger, N. I., Lieberman, M. D., \& Williams, K. D. (2003). Does exclusion hurt? An fMRI study of social exclusion. Science, 302, 290-292. doi:10.1126/ science. 1089134

Fazio, R. H., Sanbonmatsu, D. M., Powell, M. C., \& Kardes, F. R. (1986). On the automatic activation of attitudes. Journal of Personality and Social Psychology, 50, 229-238. doi:10.1037/0022-3514.50.2.229

Focus Online (2009, April 29). Einbürgerung- strengerer Sprachtest schreckt ab [Stricter language requirements deter naturalization]. Retrieved from http://www. focus.de/politik/deutschland/einbuergerungstrengerer-sprachtest-schreckt-ab_aid_394414. html $\% 23$ comment $\% 23$ comment

Fritsche, I., Jonas, E., Ablasser, C., Beyer, M., Kuban, J., Manger, A.-M., \& Schutz, M. (2013). The power of we: Evidence for group-based control restoration. Journal of Experimental Social Psychology, 49, 19-32. doi:10.1016/j.jesp.2012.07.014

Fritsche, I., Jonas, E., \& Fankhänel, T. (2008). The role of control motivation in mortality salience effects on group support and defense. Journal of Personality and Social Psychology, 95, 524-541. doi:10.1037/ a0012666

Greenaway, K. H., Louis, W. R., Hornsey, M. J., \& Jones, J. M. (2013). Perceived control qualifies the effects of threat on prejudice. British Journal of Social Psychology. Advance online publication. doi:10.1111/ bjso.12049

Greenberg, J., Pyszczynski, T., \& Solomon, S. (1986). The causes and consequences of a need for self-esteem: A terror management theory. In R. F. Baumeister (Ed.), Public self and private self (pp. 189-212). New York, NY: Springer-Verlag.

Hayes, A. F., \& Preacher, K. J. (in press). Statistical mediation analysis with a multicategorical independent variable. British Journal of Mathematical and Statistical Psychology.

Heitmeyer, W. (2006). Deutsche Zustände. Folge 4 [German conditions. Series 4]. Frankfurt, Germany: Suhrkamp.

Heitmeyer, W. (2007). Deutsche Zustände. Folge 5 [German conditions. Series 5]. Frankfurt, Germany: Suhrkamp.

Hogg, M. A. (2012). Uncertainty-identity theory. In P. A. M. van Lange, A. W. Kruglanski, \& E. T. Higgins (Eds.), Handbook of theories of social psychology (Vol.2, pp. 62-80). Thousand Oaks, CA: Sage.

Hogg, M. A., Meehan, C., \& Farquharson, J. (2010). The solace of radicalism: Self-uncertainty and group identification in the face of threat. Journal of Experimental Social Psychology, 46, 1061-1066. doi:10.1016/j.jesp.2010.05.005

Jamieson, J. P., Harkins, S. G., \& Williams, K. D. (2010). Need threat can motivate performance after ostracism. Personality and Social Psychology Bulletin, 36, 690-702. doi:10.1177/0146167209358882

Joiner, T. (2011). Lonely at the top. New York, NY: Palgrave MacMillan.

Jost, J. T., Glaser, J., Kruglanski, A. W., \& Sulloway, F. J. (2003). Political conservatism as motivated social cognition. Psychological Bulletin, 129, 339-375. doi:10.1037/0033-2909.129.3.339 
Kay, A. C., Gaucher, D., Napier, J. L., Callan, M. J., \& Laurin, K. (2008). God and the government: Testing a compensatory control mechanism for the support of external systems. Journal of Personality and Social Psychology, 95, 18-35. doi:10.1037/0022-3514.95.1.18

Kay, A. C., Whitson, J. A., Gaucher, D., \& Galinsky, A. D. (2009). Compensatory control: Achieving order through the mind, our institutions, and the heavens. Current Directions in Psychological Science, 18, 264-268. doi:10.1111/j.1467-8721.2009.01649.x

Kirkpatrick, L. A., Waugh, C. E., Valencia, A., \& Webster, G. D. (2002). The functional domain specificity of self-esteem and the differential prediction of aggression. Journal of Personality and Social Psychology, 82, 756-767. doi:10.1037/0022-3514.82.5.756

Kruglanski, A. W., \& Orehek, E. (2011). The role of the quest for personal significance in motivating terrorism. In J. P. Forgas, A. W. Kruglanski, \& K. D. Williams (Eds.), Social conflict and aggression (pp.153164). New York, NY: Psychology Press.

Leary, M. R. (2007). Motivational and emotional aspects of the self. Annual Review of Psychology, 58, 317-344. doi:10.1146/annurev.psych.58.110405.085658

Leary, M. R., Kowalski, R. M., Smith, L., \& Phillips, S. (2003). Teasing, rejection, and violence: Case studies of the school shootings. Aggressive Behavior, 29, 202-214. doi:10.1002/ab.10061

Leary, M. R., Twenge, J. M., \& Quinlivan, E. (2006). Interpersonal rejection as a determinant of anger and aggression. Personality and Social Psychology Review, 10, 111-132. doi:10.1207/s15327957pspr1002_2

Lefcourt, H. M. (1982). Locus of control: Current trends in the theory and research. Hillsdale, NJ: Lawrence Erlbaum Associates.

Maner, J. K., DeWall, C., \& Baumeister, R. F. (2007). Does social exclusion motivate interpersonal reconnection? Resolving the "porcupine problem." Journal of Personality and Social Psychology, 92, 42-55. doi:10.1037/0022-3514.92.1.42

PEW Research Center. (2011).Muslim-Western tensionspersist. Common concerns about Islamic extremism. Retrieved from http://www.pewglobal.org/2011/07/21/ muslim-western-tensions-persist/

Pickett, C. L., Gardner, W. L., \& Knowles, M. (2004). Getting a cue: The need to belong and enhanced sensitivity to social cues. Personality and Social Psychology Bulletin, 30, 1095-1107. doi: $10.1177 / 0146167203262085$

Rosenthal, R., \& Rosnow, R. L. (1985). Contrast analysis: Focused comparisons in the analysis of variance. Cambridge, UK: Cambridge University Press.
Sapolsky, R. M. (2001). A primate's memoir. New York, NY: Simon \& Schuster.

Schaafsma, J., \& Williams, K. D. (2012). Exclusion, intergroup hostility, and religious fundamentalism. Journal of Experimental Social Psychology, 48, 829-837. doi:10.1016/j.jesp.2012.02.015

Sidanius, J., \& Pratto, F. (1999). Social dominance: An intergroup theory of social hierarchy and oppression. New York, NY: Cambridge University Press.

Spiegel Online International. (2010, September 28). Continent of fear: The rise of Europe's right-wing populists. http://www.spiegel.de/international/europe/ continent-of-fear-the-rise-of-europe-s-right-wingpopulists-a-719842.html

Spiegel Online International. (2012, February 17). The far-right's respectable facade: How the NPD targets the mainstream. Retrieved from http://www.spiegel.de/ international/germany/0,1518,815787,00.html

Tajfel, H., \& Turner, J. C. (1986). An integrative theory of intergroup conflict. In S. Worchel \& W. Austin (Eds.), Psychology of intergroup relations (pp. 2-24). Chicago, IL: Nelson-Hall.

Twenge, J. M., Baumeister, R. F., DeWall, C. N., Ciarocco, J. N., \& Bartels, J. M. (2007). Social exclusion decreases prosocial behavior. Journal of Personality and Social Psychology, 92, 56-66. doi:10.1037/00223514.92.1.56

Twenge, J. M., Baumeister, R. F., Tice, D. M., \& Stucke, T. S. (2001). If you can't join them, beat them: Effects of social exclusion on aggressive behavior. Journal of Personality and Social Psychology, 81, 10581069. doi:10.1037/0022-3514.81.6.1058

Warburton, W. A., Williams, K. D., \& Cairns, D. R. (2006). When ostracism leads to aggression: The moderating effects of control deprivation. Journal of Experimental Social Psychology, 42, 213-220. doi:10.1016/j.jesp.2005.03.005

Watson, D., Clark, L. A., \& Tellegen, A. (1988). Development and validation of brief measures of positive and negative affect: The PANAS scales. Journal of Personality and Social Psychology, 54, 1063-1070. doi:10.1037/0022-3514.54.6.1063

Williams, K. D. (2007). Ostracism. Annual Review of Psychology, 58, 425-452. doi:10.1146/annurev. psych.58.110405.085641

Williams, K. D. (2009). Ostracism: A temporal needthreat model. In M. Zanna (Ed.), Advances in experimental social psychology ( Vol.41, pp. 279-314). New York, NY: Academic Press.

Williams, K. D., \& Jarvis, B. (2006). Cyberball: A program for use in research on interpersonal ostracism 
and acceptance. Behavior Research Methods, 38, 174-180. doi:10.3758/BF03192765

Williams, K. D., \& Nida, S.A. (2011). Ostracism: Consequences and coping. Current Directions in Psychological Science, 20, 71-75. doi:10.1177/0963721411402480

Zadro, L., Williams, K. D., \& Richardson, R. (2004). How low can you go? Ostracism by a computer lowers belonging, control, self-esteem, and meaningful existence. Journal of Experimental Social Psychology, 40, 560-567. doi:10.1016/j.jesp.2003.11.006
Zick, A., Küpper, B., \& Hövermann, A. (2011). Intolerance, prejudice and discrimination. A European report. Berlin, Germany: Friedrich-Ebert-Stiftung.

Zick, A., Küpper, B., \& Wolf, H. (2010). Wie feindselig ist Europa? Ausmaße von Gruppenbezogener Menschenfeindlichkeit in acht Ländern [How hostile is Europe? Degrees of group-focused emnity in eight countries]. In W. Heitmeyer (Ed.), Deutsche Zustände (pp. 39-60). Berlin, Germany: Suhrkamp. 